\title{
Greek Debt -- The Endgame Scenarios
}

\author{
Lee C. Buchheit \\ Cleary Gottlieb Steen \& Hamilton LLP - New York Office \\ G. Mitu Gulati \\ Duke University - School of Law
}

April 18, 2011

\begin{abstract}
:
Perhaps Greece -- a country with a debt to GDP already approaching 150 percent and set to move even higher -- avoids a debt restructuring. Perhaps not.

What are the possible scenarios if Greece cannot return to the capital markets to refinance this gargantuan debt stock once its EU/IMF bailout package expires in two years time? What would a Greek debt restructuring look like after mid-2013? And (sharp intake of breath here) what would happen if such a debt restructuring were undertaken before that point?
\end{abstract}




\title{
GREEK DEBT --THE ENDGAME SCENARIOS
}

\author{
Lee C. Buchheit \& Mitu Gulati ${ }^{1}$
}

At about this time last year, we wrote a short paper entitled "How to Restructure Greek Debt." ${ }^{2}$ The intervening months have seen the following major events in the Eurozone debt crisis:

- In May 2010, Greece concluded an agreement with the Eurozone member states, with the backing of the IMF, for access to a $€ 110$ billion facility (€80 billion from the Eurozone and $€ 30$ billion from the IMF). ${ }^{3}$ That amount was judged to be sufficient to allow Greece to repay -- in full and on time -all public sector debts maturing during the three-year IMF program period and to cover anticipated budget deficits during that period. One objective of this total bailout of Greece was to staunch any risk of contagion to the other European peripheral countries.

- The European Central Bank promptly embarked on a program of open market purchases of Greek and other Eurozone periphery debt in order to "ensure an orderly monetary policy transmission mechanism." ${ }^{4}$ This program continues, in fits and starts, as of this writing. The ECB is thought now to own €40-50 billion of Greek sovereign bonds purchased in the secondary market.

\footnotetext{
${ }^{1}$ Partner, Cleary Gottlieb Steen \& Hamilton LLP (New York) and Professor, Duke Law School, respectively.

${ }^{2}$ Available at http://papers.ssrn.com/sol3/papers.cfm?abstract id=1603304. The published version of this paper can be found at Lee C. Buchheit \& Mitu Gulati, Restructuring a Nation's Debt, Int'l Fin. L. Rev. 46 (June 2010). A copy is attached to this document.

${ }^{3}$ See Ronald Janssen, Greece and the IMF: Who Exactly is Being Saved? CEPR Draft (July 2010) (available at http://www.cepr.net/documents/publications/greece-imf-2010-07.pdf).

${ }^{4}$ See Ansgar Belke, Driven by the Markets? ECB Sovereign Bond Purchases and the Securities Market Program, Directorate General for Internal Policies, Working Paper (June 2010) (available at http://www.europarl.europa.eu/document/activities/cont/201006/20100610ATT75796/20100610ATT75796 EN.pdf).
} 
- On October 18, 2010, German Chancellor Angela Merkel and French President Nicholas Sarkozy took a stroll on a beach in Deauville, France. When they returned holding hands (in a figurative sense, naturally), they announced plans to alter the EU treaty to put in place a permanent "crisis management system" that would include provisions to ensure the "adequate participation of private creditors". ${ }^{5}$ Unfortunately, Mr. Sarkozy and Mrs. Merkel did not confide to the markets precisely what this "adequate participation" entailed. Predictably, the markets assumed the worse, resulting in a sell-off of Eurozone periphery sovereign debt. ${ }^{6}$ Yields on that paper moved sharply higher.

- In late November 2010, Ireland asked for, and received, its own €85 billion bailout package, also with IMF conditionality. ${ }^{7}$

- To calm the markets after the Deauville adventure, the finance ministers of the five biggest EU member states announced on November 28, 2010 that "any private sector involvement [in Eurozone sovereign debt restructurings] ... would not be effective before mid-2013". ${ }^{8}$ In other words, investors were assured -- or thought they had been assured -- that all existing Eurozone sovereign debt instruments would be immune from a debt restructuring.

- On March 8, 2011, Greece filed a registration statement with the U.S. Securities and Exchange Commission enabling the country to issue bonds to "diaspora" Greek investors at rates significantly below market. ${ }^{9}$

${ }^{5}$ See Erick Nielsen, Eurozone Bond Haircuts Must Look Appealing, Financial Times, November 9, 2010.

${ }^{6}$ See Peter Spiegel, Anger at Germany Boils Over, Financial Times, November 16, 2010; Simon Tilford, Eurozone Politicians are Playing with Fire, CER Insight, November 15, 2010.

${ }^{7}$ See lan Traynor, IMF and EU bail out Ireland amid fears of Eurozone contagion, The Guardian, November 22, 2010.

${ }^{8}$ Statement by the Eurogroup, available at http://www.consilium.europa.eu/uedocs/cms data/docs/pressdata/en/ecofin/118050.pdf

${ }^{9}$ A Greek Diaspora Bond Odyssey, Financial times (Alphaville), March 9, 2011 (available at http://ftalphaville.ft.com/blog/2011/03/09/509211/a-greek-diaspora-bond-odyssey/). 
- On April 6, 2011, as this paper was being written, Portugal asked the European Union for financial assistance. ${ }^{10}$

- March 23, 2011 saw the release of a term-sheet for a permanent facility to assist distressed Eurozone sovereigns after 2013, the European Stabilization Mechanism ("ESM"). The term sheet makes clear that ESM loans will be given preferred creditor status. ${ }^{11}$ A similar claim to preferred creditor status has not been made (or at least not yet been made) for the $€ 80$ billion EU contribution to the Greek bailout package.

- Last month, the Greek Finance Minister said publicly that even the $€ 110$ billion EU/IMF facility might not be enough to tide Greece over until 2013. ${ }^{12}$

To date, one or more of the following concerns about permitting a restructuring of Eurozone sovereign debt have induced the official sector to continue a policy of total bailouts of all afflicted countries.

- Contagion. Confronted with a debt restructuring in one country, will the markets recoil from all peripheral Eurozone countries, perhaps sparking a general crisis?

- Effect on banks. Eurozone commercial banks hold the lion's share of Greek sovereign bonds. A debt restructuring that significantly reduced the balance sheet valuation of these assets could threaten the solvency of some institutions, perhaps requiring a recapitalization from the host government.

- Honi soit qui mal y pense. Would a Eurozone sovereign debt restructuring indelibly stain the reputation of the Euro and perhaps even undermine the foundations of the monetary union itself?

${ }^{10}$ See Peter Wise and Peter Spiegel, Portugal appeals for EU bail-out, Financial Times, April 7, 2011.

${ }^{11}$ See the Eurozone's ESM Permanent Bailout Fund, Financial Mirror, March 23, 2011 (available at http://www.financialmirror.com/Columnist/Global Markets/752).

${ }^{12}$ Id. 
Although each of these constraints is still present to some degree one year after the Greek debt crisis erupted, it is no longer obvious that they, individually or in aggregate, continue to justify complete paralysis. The markets have had an opportunity to focus on the differences in the financial positions of the various peripheral Eurozone countries. Putting aside the obvious fact that the policy of total official sector bailouts has not prevented contagion (see Ireland and Portugal), blind indiscriminate contagion has diminished as a risk. As for the commercial bank holders, they have been given a year to sell or hedge exposures, or otherwise provision against an eventual hit to the value of their Greek positions. Some are no doubt still uncomfortably exposed, but this list should be smaller than it was a year ago. (It is not clear to us whether all banks have in fact made hay while this sun has been shining, but they have at least been given a chance to do so.)

We have now been asked to update our earlier assessment of the Greek debt situation in light of these developments. In particular, we have been asked to speculate on possible endgame scenarios for the Greek debt crisis.

We divide these scenarios into three groups: (i) Greece goes the distance with the current IMF/EU program and a debt restructuring is avoided altogether, (ii) a debt restructuring of some kind becomes unavoidable after June 2013 when the EU's "read my lips -- no restructuring until 2013" promise lapses by its terms, and (iii) a liability management transaction affecting some or all of the Greek debt stock is launched before 2013.

\section{The Official Scenario -- Greece Goes the Distance}

Under this scenario -- which enjoys the public support of Greece's official sector sponsors (the IMF and the EU) as well as the Greek authorities themselves -- Greece will stick with its program of fiscal austerity for the full three years. At the end of that period (apparently the initial prediction of renewed market access in 2012 has now been withdrawn), Greece returns to the capital markets to refinance its maturing debt and fund amortizations due on the EU/IMF bailout loans. The markets, this theory contends, will be so impressed with the turnaround in Greece's fiscal position that private sector monies will be advanced in sufficient quantities and at tolerable interest rates to permit Greece to resume normal rollovers of its maturing debts. Over time, Greece will run primary budget surpluses and will begin to nibble at its (admittedly) colossal debt stock. This, says the official sector, is the benignant future that awaits both Greece and all of its lenders. 


\section{The Risks}

- On its current path, the Greek public sector debt in 2013 will represent $150-170 \%$ of GDP. Moreover, more than half of that debt stock will by then be in the hands of official sector creditors (the EU, the ECB and the IMF), at least one of which (the IMF) claims for itself preferred creditor status. Will the private capital markets really be eager to resume financing a country in this precarious position?

- Two more long years of fiscal austerity lay ahead for Greece. Will the Greek politicians be able to hold the social/political consensus together that long?

- What happens if Greece begins to miss its IMF performance targets? Will the IMF and EU casually relax the conditionality so that drawdowns can continue under the $€ 110$ billion facility, or might German parliamentarians insist on taking a harder line? Waiving compliance with the fiscal performance targets in order to avoid a debt default, of course, risks sending this message to other prospective borrowers from official sector bailout facilities: "Eurozone countries in financial distress can expect assistance from the EU and IMF in two -- but only two -- circumstances: (i) when those countries adopt and stick to stern fiscal austerity programs or (ii) when they don't".

- The $€ 110$ billion facility was intended by its authors to be an overwhelming demonstration of financial firepower -- a veritable Hank Paulson bazooka. If this was the antidote to contagion, however, it failed. Ireland has succumbed. So has Portugal. If one of these other countries decides to pursue a debt restructuring before 2013, might not that precedent fuel calls for something similar in Greece? 


\section{$\underline{\text { Post-2013 Scenarios }}$}

We see four possible scenarios if Greece is unable to regain market access in late 2013. Three involve a post-2013 restructuring of the Greek debt stock, while one envisions that Greece muddles on for an indefinite period as a ward of the official sector.

Scenario One: The Official Sector Takes the Spear. By June 2013, more than one-half of the Greek debt stock will be in the hands of official sector lenders. By significantly restructuring their own claims against the country, these official sector lenders could attempt to render Greece presentable to the private markets.

\section{The Risks}

- It is difficult (read, nearly inconceivable) to envision a political environment that would permit the EU and ECB -- much less the IMF -- to sacrifice their taxpayers' money in order to ensure full and timely repayment of commercial creditors, some of whom are earning yields in excess of $12 \%$.

- Will the EU carry the burden of such a restructuring alone, or will it expect the IMF to chip in? And if the latter, what, if anything, will be left of the IMF's sacrosanct "we never restructure" status?

Scenario Two: The Private Sector Creditors Take the Spear: Under this scenario, the holders of the remaining Greek debt stock still in private hands in mid-2013 will be presented with a restructuring proposal that effectively eviscerates the value of their paper.

\section{$\underline{\text { The Risks }}$}

- Even a total write-off of that remaining one-third to one-half of the debt stock may not be enough to return Greece to creditworthiness.

- These creditors will never go gentle into the good night of a total loss of value. Something coercive, something truly ugly, will be needed to prod them into the abattoir. What effect would this have on future lending to Greece or, for that matter, to other Eurozone sovereigns? 
Scenario Three: All Together Now. The third alternative involves a joint debt restructuring by both official and private sector lenders sometime after the middle of 2013. With private sector involvement, the official sector can't be accused of mollycoddling commercial lenders; with official sector involvement, those commercial lenders would not face a total write off of the value of their claims.

\section{The Risks}

- Some might argue that this demonstration of fraternal solidarity will only end up alienating the affections of both groups, the official and the private lenders. Would it not be better, they might argue, to keep one camp sweet for future borrowings?

- Unless the terms of the two restructurings were calibrated to be equivalent in a net present value sense, this approach risks intercreditor jealousy and suspicion.

Scenario Four: Wardship. Perhaps the paralyzing fear of a Eurozone sovereign debt restructuring will persist even after 2013 has come and gone. If so, Greece could be relegated to the status of a ward of the official sector for an indefinite period. The remaining bonds in the hands of commercial lenders, and the amortizations due on the first round of EU/IMF loans, would presumably all be paid with the proceeds of drawings under successor official sector credit facilities. After the passage of a few more years, virtually all of the Greek debt stock will then be owed to its official sector rescuers.

\section{$\underline{\text { The Risks }}$}

- This could be politically unpalatable to the Greeks. Someone is bound to say that when Greece took the first $€ 110$ bailout, this was equivalent to a bibulous landlubber accepting the King's schilling from the sergeant of a Royal Navy press gang in order to buy one more round of drinks: when the poor fellow wakes up in the morning he will be facing ten years before the mast in His Majesty's service. 
- It can't be a very pleasant alternative for the official sector either.

\section{Pre-2013 Restructuring Scenarios}

If for any reason Greece cannot, or does not wish to, wait until mid2013 before addressing its debt stock (a decision that presumably would require at least the passive acquiescence of the EU, the IMF and the ECB), broadly speaking we see two possible scenarios.

The EU's post-Deauville assurance that there will never be a restructuring of an existing Eurozone sovereign debt instrument (at least until 2013) presents something of an obstacle to any pre-2013 restructuring of Eurozone sovereign debt instruments. The face-saving solution may be linguistic. A voluntary liability management transaction undertaken by the debtor country before 2013 , the argument goes, is not a "restructuring" as that term was used in the post-Deauville assurance. Restructuring, it may be claimed, connotes a degree of coercion on the affected creditors. But if the creditors themselves elect voluntarily to participate in a liability management transaction to improve the creditworthiness of their debtor, who in the official sector can or should gainsay that decision?

Scenario One -- A Light Dusting. One possibility would be to approach the private sector (principally northern European commercial bank) holders of Greek bonds with a mild restructuring proposal that limits, or even neutralizes altogether, any net present value loss they would suffer as a result of participating in the transaction. A simple Uruguay-style ${ }^{13}$ reprofiling of the debt stock with no haircut to principal would fit this bill. To ensure widespread creditor acceptance, some might urge that any new instrument issued to effect the restructuring benefit from credit enhancement (a partial guarantee from the official sector, for example, or collateral security à la Brady bonds) so as to neutralize the negative NPV consequences of the stretch-out of maturities. One obvious motivation for a mild restructuring of this kind would be to cushion its effect on the balance sheets of overexposed northern European commercial banks. A second motivation, of course, would be to move existing debt maturities beyond the current program period so as to liberate a portion of the $€ 110$ billion bailout facility for other purposes.

\footnotetext{
${ }^{13}$ In 2003, Uruguay "reprofiled" its external debt stock by extending the maturity of each of its 18 series of bonds by five years. There was no haircut to principal; coupons were kept the same. See Lee C. Buchheit and Jeremiah S. Pam, Uruguay's Innovations, 19 J. Int'I Banking L. and Reg. 28 (2004).
} 


\section{The Risks}

- Will such a light dusting of the debt stock return Greece to a sustainable position, or will it be just the first of a two stage restructuring with the real blood-letting deferred to stage two?

- Neutralizing the negative NPV effect of a maturity stretch out by adding credit enhancements is expensive and contraindicated for a country facing a severe debt crisis. But asking bondholders voluntarily to accept an NPV loss, however, will surely test the sponsors' powers of persuasion.

- Overexposed commercial banks that currently hold Greek sovereign paper in their "hold to maturity" book at or near par value may want an assurance that a transaction of this kind will not require an immediate marking of their positions to market values.

Scenario Two: The Full Monty. For the sake of completeness, the final option would involve a full restructuring of the Greek debt stock prior to 2013 in order to give the country a visibly sustainable debt profile as soon as possible. Such a restructuring would presumably look to cut the size of the debt stock in nominal terms as well as to iron out the maturity profile, all to the end of positioning Greece to return to the capital markets within a reasonable period of time following the closing of the transaction.

\section{$\underline{\text { The Risks }}$}

- A Full Monty approach would require all concerned to jettison any illusions about sponsoring a wholly voluntary transaction.

- This will lead to the usual discussion about how -- in the odious patois of investment bankers -- to "incentivize" the bondholders to participate. Change local law to compel participation (more than $90 \%$ of the debt stock is governed by Greek law)? Threaten a payment default on any untendered bonds (the "abandon all hope ye who do not enter here" tactic)? Declare any non-tendered bonds ineligible at the ECB discount window?

- Having spent billions of Euros of taxpayer money to stave off any restructuring of Eurozone sovereign debt, will the political class in Europe really be prepared now to careen to the other extreme of countenancing a savage debt restructuring? 
- A major tremor of this kind affecting the Greek debt would indeed be felt in Lisbon, Madrid and elsewhere in peripheral Europe.

\section{The Historical Perspective}

We have all been here before.

In August of 1982, Mexico was forced to declare a moratorium on the repayment of its external debt owed to commercial banks. Over the course of the next two years, more than twenty other countries followed suit -- it later came to be called "the global debt crisis" of the 1980s.

Then, as now, the lenders to these sovereigns were primarily commercial banks. Then, as now, some of those banks were dangerously overexposed and could not have endured any significant writedown of the value of their sovereign credit portfolios. Then, as now, the banks approached the official sector institutions asking that the official sector either lend the sovereign borrowers the money to continue normal debt service on their bank credits or, failing that, guarantee the banks' loans.

Then, unlike now, the banks were rebuffed. The official sector flatly refused to bail the banks out of their bad credit decisions in the early 1980s. But, in recognition of the balance sheet fragility of some of those institutions, the official sector (and in particular the U.S. Treasury) agreed to use its influence over the sovereign debtors to promote a debt restructuring technique that avoided any need for the banks to write down the value of their sovereign portfolios.

This technique, later named after U.S. Treasury Secretary James Baker, had four components.

- The debtor country was required to sign up to an IMF stabilization and adjustment program.

- The principal of the banks' loans was rescheduled over relatively brief periods -- 18 to 24 months.

- Interest payments on those rescheduled loans, however, had to be kept current to avoid negative accounting consequences for the banks. 
- Because many countries lacked the resources even to pay interest, the banks were compelled to lend the debtors "new money" which was then recycled back to the banks as interest payments on their existing exposure. ${ }^{14}$

As the 1980s rolled sweetly on, the four elements of this Baker Plan debt restructuring technique were repeated, sometimes four or five times, in the afflicted debtor countries. In public, Secretary Baker and others expressed fathomless confidence that the banks would never experience a loss on their sovereign credits. Why? The debtor countries, it was predicted, would after years of IMF tutelage "grow" out of their debt problems. In private, however, the official sector players warned the commercial banks to begin provisioning their loan loss reserves against the possibility that a loss might someday materialize.

After seven years of the Baker Plan, a new U.S. Treasury, Nicholas Brady, announced (on March 10, 1989) a shift in U.S. Government policy toward the management of the global debt crisis. Secretary Brady encouraged the banks to write off a portion of their exposure to the debtor countries, and to stretch out repayment of the balance for 30 years, as a means of ending the global debt crisis in a single stroke. And, more or less, the Brady Initiative did just that. Banks swallowed (modest) losses on their sovereign portfolios; debtor countries regained (modest) market access; the banks' loan loss reserve provisions (built up over the prior seven years) cushioned the balance sheet effect of the losses. A banking crisis in the developed countries did not follow the launch of the Brady Initiative.

The debt management technique adopted by Secretary Baker and his official sector colleagues in 1982 therefore had the effect of grabbing the commercial bank creditors by their noses and holding them in place as the lenders of record until a more durable solution to the problem could be implemented. The concession made to the bank lenders at the time was a restructuring technique that avoided accounting losses while the banks were provisioning their loan loss reserves. When the day of reckoning eventually arrived with Secretary Brady, the losses were felt by the bank creditors that had made the loans in the first place.

${ }^{14}$ See Buchheit, "Whatever Became of Old New Money", Int'l Fin. Law Review, December 1990. 
Contrast this to the debt management technique being used in Europe in 2010-2011. This time around, the official sector players are not holding the original lenders by the nose; the official sector is actually buying out the original lenders in full and on time as each existing bond matures and is paid by drawing down an official sector credit lines. The difference is this -- if the sword of a debt restructuring must eventually fall in order to render Greece's debt stock manageable (something that most economists view as inevitable), that sword will fall principally on the neck of the official sector lenders. The original creditors will have swapped places in the tumbrel with official lenders quite literally in the shadow of the guillotine.

Attachment:

Lee C. Buchheit \& Mitu Gulati, How to Restructure Greek Debt (May 2010) (available at http://papers.ssrn.com/sol3/papers.cfm?abstract id=1603304). 
Draft

$5 / 7 / 10$

\title{
How to Restructure Greek Debt
}

\author{
Lee C. Buchheit \\ G. Mitu Gulati
}

\begin{abstract}
$\underline{\text { Abstract }}$
Plan A for addressing the Greek debt crisis has taken the form of $a € 110$ billion financial support package for Greece announced by the European Union and the International Monetary Fund on May 2, 2010. A significant part of that $€ 110$ billion, if and when it is disbursed, will be used to repay maturing Greek debt obligations, in full and on time. The success of Plan $A$ is not inevitable; among other things, it will require the Greeks to accept -- and to stick to -- a harsh fiscal adjustment program for several years.
\end{abstract}

If Plan A does not prosper, what are the alternatives? And how quickly could a Plan $B$ be mobilized and executed?

This paper outlines the elements of one possible Plan $B, a$ restructuring of Greece's roughly $€ 300$ billion of government debt. Prior sovereign debt restructurings provide considerable guidance for how such a restructuring might be shaped. But several key features of the Greek debt stock could make this operation significantly different from any previous sovereign debt workouts.

To be sure, a restructuring of Greek debt will not relieve the country from the painful prospect of significant fiscal adjustment, nor will it displace the need for financial support from the official sector. But it may change how some of those funds are spent (for example, backstopping the domestic banking system as opposed to paying off maturing debt in full).

This paper does not speculate about whether a restructuring of Greek debt will in fact become necessary or politically feasible. It focuses only on the how, not the whether or the when, of such a debt restructuring. 
Draft

$5 / 7 / 10$

\title{
How to Restructure Greek Debt
}

\author{
Lee C. Buchheit \\ G. Mitu Gulati
}

This paper offers no opinion on whether Greece's debt should be restructured and, if so, when or on what financial terms. Nor does it speculate on what consequences, intended or unintended, might flow from such a restructuring. We will limit ourselves solely to the issue of how such a restructuring might efficiently be undertaken -- drawing on the lessons of past sovereign debt restructurings (successful and otherwise) -- if a decision is made to proceed with a debt restructuring at some point in the future.

\section{Financial Aspects of the Debt Stock}

Greece's total debt as of end-April 2010 was approximately $€ 319$ billion. Of that figure, the vast majority -- approximately $€ 294$ billion -was in the form of bonds, with another $€ 8.6$ issued as Treasury bills.

Virtually all of this debt stock was denominated in Euros. Small amounts (in aggregate, less than $2 \%$ of the total) are outstanding in U.S. dollars, Japanese yen and Swiss francs.

Information about the holders of Greek bonds is anecdotal. From press reports, however, it appears that French and German banks have the heaviest exposures, ${ }^{1}$ but mutual funds, pension funds, hedge funds and other categories of investors also own Greek bonds. Significantly, the extent of retail (non-institutional) ownership appears to be small.

\footnotetext{
* Cleary Gottlieb Steen \& Hamilton, LLP

** Duke University Law School

${ }^{1}$ James Wilson et al., "Worries persist on exposure to Greece," Fin. Times, April 30, 2010.
} 
A significant amount of Greek bonds have been discounted by European commercial banks with the European Central Bank ("ECB"). On May 3, 2010, the ECB announced that those bonds would continue to be eligible for discounting, notwithstanding the downgrading of Greek bonds below investment grade that occurred the prior week. ${ }^{2}$

\section{Legal Aspects of the Debt Stock}

Governing law. From the legal standpoint, the salient feature of Greece's bond debt is that approximately $90 \%$ of the total is governed by Greek law. Only about $€ 25$ billion of the bond debt was issued under the law of another jurisdiction, and most of that under English law.

Collective action clauses. It does not appear from our survey of Greek bond documentation that the instruments issued under local law contain provisions permitting the holders to amend the terms of the bonds after issuance (other than to correct obvious errors or technical matters). Prior to 2004, Greek bonds issued under English law contained collective action clauses ("CACs") that appear ${ }^{3}$ to permit holders of 66 percent of an issue to modify payment terms in a manner that would bind all other holders. After 2004, Greece altered this clause in its English law bonds. ${ }^{4}$ This new version of the CAC permits amendments to payment terms of a bond, as well as certain other key features of the instrument, with the consent of holders of $75 \%$ or more of an issue.

Negative Pledge. Greece does not appear to have included a negative pledge clause in its bonds issued under local law.

\footnotetext{
${ }^{2}$ See Press Release, ECB Announces Change in Eligibility of Debt Instruments Issued or Guaranteed by the Greek Government (May 3, 2010) available at http://www.ecb.int/press/pr/date/2010/html/pr100503.en.html).

${ }^{3}$ We say "appear" because the descriptions of the modification clauses in the Offering Circulars for these bonds routinely conflate the notion of a quorum (that is, the number of bonds required to activate a meeting of bondholders) with the percentage of bonds required to approve an Extraordinary Resolution.

${ }^{4}$ In 2002, a working group of the G-10 issued a report recommending reform of the standard sovereign debt contract. See Report of the G-10 Working Group on Contractual Clauses (September 2002) (available at http://www.bis.org/publ/gten08.htm). The Report contained a recommended version of a collective action clause for sovereign bonds as well as other model clauses. The new Greek CAC derives from this source.
} 
The foreign law Greek bonds we have examined do contain a negative pledge clause, but in a very unusual form. This clause requires Greece equally and ratably to secure each of these bond issues if ever it creates or permits to subsist any form of security interest over its revenues, properties or assets to secure any "External Indebtedness."

In the case of a typical emerging market sovereign bond, external indebtedness is defined to cover borrowings denominated in a currency other than the currency of the issuing State. And so it was with Greek bonds issued prior to January 1, 2000 when the Euro was adopted as the common currency of the European Union. After that date, however, the Euro became the "lawful currency" of Greece. But Greece's form of negative pledge clause did not change for more than four years after the adoption of the Euro ${ }^{5}$; the "lawful currency" just quietly ceased being the Drachma and became instead the Euro. In practical terms, this means that Greece's negative pledge clause in its foreign law bonds issued prior to 2004 would only be triggered by the creation of a lien to secure a non Euro-denominated Greek debt.

Events of Default. Most of the Greek bonds we have examined incorporate a standard set of Events of Default (variations can be found in a few bonds). These include:

- failure to pay interest (with a 30-day grace period);

- other covenant defaults (with a 30-day grace period after written notice to the issuer);

- "External Indebtedness" (above a de minimis threshold) is accelerated, or a payment is missed under such External

\footnotetext{
${ }^{5}$ Starting in 2004, the definition of "External Indebtedness" in Greece's foreign law-governed bonds changed. Under the new version of the definition, indebtedness for borrowed money is "External" if either (i) it is denominated in a currency other than Euros or (ii) borrowed from foreigners under a foreign law-governed contract. This change in Greece's standard bond documentation occurred at roughly the same time as the country began using a CAC modeled on the G-10 recommended clause, and adopted a $25 \%$ voting threshold for acceleration (also recommended by the G-10).
} 
Indebtedness and continues beyond the specified grace period $;^{6}$

- a general moratorium is declared on "External Indebtedness"; and

- any government order or decree prevents Greece from performing its obligations under the bonds.

The important point to note here is that the cross-acceleration, cross-default and moratorium event of default clauses in these bonds apply only to External Indebtedness; a term that in Greek bonds issued prior to 2004 excludes Euro-denominated obligations. Thus, these Events of Default in pre-2004 bonds could only be triggered by an event affecting the small amount of Greek debt that is denominated in currencies other than Euros. Stated differently, a payment default on a Greek Euro-denominated bond, or the acceleration of such an instrument, would not have cross-default consequences across much of the debt stock. ${ }^{7}$

Bondholder remedies. Prior to 2004 (when Greece adopted a new form of $\mathrm{CAC}$ ), individual bondholders could accelerate their bonds following the occurrence of an Event of Default. Bonds issued after that time incorporate a requirement that holders of $25 \%$ of the bonds vote in favor of an acceleration -- one of the provisions recommended by the G-10 Working Group on Contractual Clauses in 2002. (Individual rights of acceleration are now rarely found in emerging market sovereign bonds.)

\section{Greece in a Restructuring Context}

Greece would enjoy some distinct advantages in the restructuring of its debt, as well as a few disadvantages, in comparison with other countries that have been forced to undergo the process.

\section{$\underline{\text { Advantages }}$}

- Greece's debt is overwhelming in the form of bonds, a characteristic shared by countries like Argentina (2001-05),

\footnotetext{
${ }^{6}$ These cross-acceleration and cross-default clauses appear in some, but not all, of Greece's bonds issued under local law.

${ }^{7}$ In Greek bonds issued after 2004, these Events of Default would be triggered by an event affecting Republic debt that was either non Euro-denominated or borrowed from foreigners under a foreign-law governed agreement.
} 
Ecuador (2000) and Uruguay (2003). Greece will therefore be able to avoid the complexities and intercreditor rivalries that can be occasioned by a diverse creditor universe. Iraq (2005-08), for example, faced a commercial creditor class composed of banks, suppliers, construction companies, various kinds of trade creditors and even individuals. In the end, Iraq had to settle more than 13,000 individual claims dating back to the Saddam era.

- Greece's debt records are fresh and up to date. When sovereign debts have been in default for prolonged periods before they are restructured (for example, Liberia (2009) -more than 25 years in arrears; Iraq (2005-08) -- more than 15 years in arrears), the task is much harder.

- Greece enjoys considerable financial support from multilateral and bilateral sources. This opens up the possibility of being able to "credit enhance" any new Greek debt instrument that might be issued as part of a debt restructuring. Greece is therefore in a position similar to the countries that issued collateralized Brady Bonds starting in 1990.

- Related to the last point, the odd nature of Greece's negative pledge clauses noted above (the clauses in bonds issued prior to 2004 would not be triggered by the creation of liens to secure future Euro-denominated indebtedness of Greece) means that some form of collateralized Brady Bond approach might be legally feasible for Greece without having to obtain waivers of negative pledge restrictions in foreign law-governed instruments issued prior to 2004.

- The fact that so few Greek bonds seem to have fallen into the hands of retail (non-institutional) investors may also be a blessing. Those countries (for example, Argentina (200105)), that have had to deal with thousands of retail bondholders in a debt restructuring have found this a messy and thankless task.

- By far, however, the greatest advantage that Greece would enjoy in a restructuring of its debt derives from the fact that so much of the debt stock is expressly governed by Greek law $(90 \%$ or more, if our figures are correct). This raises the 
possibility, discussed in more detail below, that the restructuring could be facilitated in some way by a change to Greek law.

Several other countries have restructured local lawgoverned debts. Russia restructured Russian law-governed instruments known as GKOs and OFZs in 1998 in parallel with the restructuring of its English law commercial bank debt. Uruguay restructured its local law bonds (on the same terms as its foreign law bonds) in 2003. In each of these prior cases, however, the local law bonds were also denominated in local currency and formed only part of the overall stock of the debt being restructured. While the Euro is certainly now the local currency of Greece, it is a good deal more besides that.

No other debtor country in modern history has been in a position significantly to affect the outcome of a sovereign debt restructuring by changing some feature of the law by which the vast majority of the instruments are governed.

\section{Disadvantages}

Several features of the Greek situation may complicate any restructuring of its debt.

- A significant percentage (perhaps more than 30 percent) of the bonds are believed to be owned by Greek institutional holders. A restructuring that dramatically impairs the value of that paper could therefore place further strains on the Greek domestic financial sector. Jamaica, which restructured its local currency debt earlier this year, had to walk very gingerly in designing its transaction because so much (perhaps as much as 75\%) of the affected paper was held by Jamaican financial institutions.

- European banks are the largest holders of Greek bonds. The stability of those institutions will be therefore very much on the minds of Greece's multilateral and bilateral supporters should a debt restructuring prove unavoidable.

The sovereign debts that triggered the global debt crisis of the 1980 s were nearly all owed to international commercial 
banks. When the debt crisis broke in 1982, the official sector overseers of the restructuring process therefore had to keep one eye on the debtor countries and the other on the stability of the banking systems in the industrialized creditor countries. It remained an uncomfortable position for nearly seven years until the banks had time to build up the loan loss reserves that permitted them to accept losses in Brady Bond exchanges without alarming regulators, stockholders or their own creditors.

In contrast, sovereign debt crises of the last 10 years or so have affected mostly non-bank creditors -- hedge funds, pension funds, other institutional holders of emerging market sovereign debt, sometimes even individuals. Those crises did not threaten the stability of the banking sectors in creditor countries.

A restructuring of Greek debt will, in this respect, rekindle fretful memories of the global debt crisis of the 1980s in the minds of official sector observers.

- Greece's debt is denominated in Euros, a currency shared by other members of the European Union. When a Mexico or a Philippines restructured debts denominated in U.S. dollars in the 1980s, no one -- for that reason alone -- lost confidence in the U.S. dollar. This same assurance cannot be given about the restructuring of Euro-denominated debts owed by an EU Member State.

\section{How Might It Be Done?}

Which brings us to the main event. If one were to attempt to glean the lessons of the 50 or 60 sovereign debt restructurings of the modern era, what would they teach about how a Greek debt restructuring should be managed in order to achieve a prompt, orderly and fair outcome? There is one lesson from this history that is inescapable. A sovereign debt crisis can be a painful experience for both the debtor and its creditors; a mismanaged sovereign debt crisis can be a catastrophically painful experience.

Transaction structure. The most likely structure for such a transaction would be an exchange offer -- new bonds of the Hellenic Republic would be offered in exchange for the Republic's existing bonds. The terms of the new bonds would determine the nature and extent of the 
debt relief that the transaction would provide to Greece. Exchange offers have been the norm for sovereign debt restructurings of middle income countries since the first Brady Bond transactions in 1990.

Eligible debt. The debt eligible to participate in such an exchange would presumably be all outstanding Greek bonds, excluding perhaps the Treasury bills. Short-term Treasury bills have been excluded from a number of recent sovereign debt restructurings in order to keep that market sweet for the government's emergency financing needs.

An interesting question will be whether some way can be found to exclude from the restructuring the bonds in retail hands, or at least to moderate the terms of any restructuring of those bonds. This will depend on two things. First, the total amount of bonds in the hands of natural persons would have to be relatively small. Institutional holders may recognize the public relations benefit of not having widows and orphans complaining on the evening news, but only up to a point. If the exclusion of retail holders appreciably increases the severity of the financial sacrifice that must be borne by institutional creditors, these sympathies will quickly fade. Second, some mechanism must be found that will permit the government to identify which bonds are in retail hands when the restructuring is announced. Otherwise, bonds will tend to migrate temporarily into the hands of individuals until the restructuring storm passes over.

New instruments. The terms of the new instrument or instruments that would be offered in such an exchange will be a function of the nature and extent of the debt relief the transaction is designed to achieve. At the soft end of the spectrum would be a simple "reprofiling" of existing bonds (or some discrete portion of them such as bonds maturing over the next three to five years) involving a deferral of the maturity date of each affected bond. Uruguay (2003) stretched out the maturity date of each of its bonds by five years, while leaving the coupons untouched.

At the sharper end of the spectrum would be a transaction designed to achieve a significant net present value ("NPV") reduction in the stock of debt. If Brady Bonds were chosen as the model for the transaction, this might entail allowing holders to elect to exchange their existing credits for either a Par Bond (a new bond exchanged at par for existing instruments, having a long maturity and a low coupon), or a Discount Bond (a new bond exchanged for existing instruments at a discount from the face amount of those instruments, but typically carrying a higher coupon and perhaps a shorter maturity than the Par Bond). The precise financial terms of the Par 
Bond and the Discount Bond would be calibrated to achieve an equivalent NPV reduction.

CACs. Some version of a collective action clause appears in most of Greece's foreign law-governed bonds. There is no reason not to use these clauses to minimize the number of non-participating creditors.

It would work as follows: each tender of an existing bond containing a CAC would contain a power of attorney from the owner of that bond in favor of the government (or its exchange agent) to vote that bond at a bondholders' meeting (or in a written action by bondholders) in favor of a resolution that, if approved by the requisite supermajority of holders of that instrument, would either cause the totality of that bond to be tendered in the exchange or cause the payment terms of the bond to be amended so as to match the terms of one of the new instruments being offered in the exchange. Such a resolution, if approved by the requisite supermajority of holders (66\% or $75 \%$ in Greek bonds governed by English law) would automatically bind all holders.

Creditor consultations. As part of the restructuring process, Greece would have to consult with significant holders of its paper, or with committees or other ad hoc groups representing those holders. Such consultations would be necessary to garner widespread support for the restructuring. In addition, the IMF's so-called "Lending Into Arrears" policy requires a member country facing a debt restructuring to make "a good faith effort to reach a collaborative agreement with its creditors".

Credit enhancement. If Greece's multilateral and bilateral supporters were prepared to allow some portion of their emergency financing to be used for this purpose, Greece might be able to enhance to attractiveness of the new bonds it would offer in the exchange. In the typical Brady Bond context, for example, the issuing countries borrowed money from the IMF and the World Bank and used those funds to purchase U.S. Government zero coupon obligations that were then pledged to secure the principal payment due on the Brady Bonds at maturity. In many cases, a pool of cash equal to 12-24 months of interest accruals on the Brady Bonds was also set aside and pledged as partial security for the interest due on the Brady Bonds. So the Brady Bonds represented U.S. Government risk for principal due at maturity, and issuing country risk for interest during the life of the Bond (apart from any amount pledged as rolling interest collateral).

The negative pledge clauses in the debt instruments of the Brady countries did not pose an insuperable obstacle to these collateralized 
transactions. The commercial bank creditors waived the application of the negative pledge restrictions in their agreements, as did the World Bank and other multilateral development banks. In the small number of cases where a Brady country also had outstanding international bonds, arrangements were put in place to post "equal and ratable security".

For the reasons noted above, Greece's negative pledge clauses contained in bonds issued prior to 2004 would not protect holders of those bonds in the event that Greece were to collateralize a future Eurodenominated issue of securities. In the case of existing bonds with negative pledge clauses that would be triggered by the issuance of a new collateralized security, Greece would presumably seek a waiver of the negative pledge restrictions when it invited tenders of those issues in the exchange offer. Failing receipt of such a waiver, Greece would be obliged to post "equal and ratable" collateral for that issue of bonds.

Credit enhancement need not take the form of collateral security. Indeed, over time, the market grew less fond of Brady Bonds and most countries have retired their Brady Bonds early. Obtaining a partial guarantee of the new instruments from a creditworthy party is another option. (The Seychelles obtained a partial guarantee from the African Development Bank of the new debt instrument issued by the Seychelles in connection with its debt restructuring earlier this year.) Another alternative would be to offer holders of the new instruments a continuing "put" of those instruments to a creditworthy party, presumably at some discount from face value. This would allow an institutional holder of the paper to ensure that the instrument will always have a minimum floor value, no matter what happens to the trading price in the secondary market.

\section{The Tactical Implications of Local Law Bonds}

International investors are often leery of buying debt securities of emerging market sovereign issuers that are governed by the law of the issuing state. Why? Because investors fear that the sovereign might someday be tempted to change its own law in a way that would impair the value or the enforceability of those securities. Such changes in local law would normally be respected by American and English courts if the debt instruments are expressly -- or otherwise found to be -- governed by that local law.

International capital market borrowings by industrialized countries sometimes follow a different model. Many of these countries have found that foreign investors are prepared to purchase local law-governed 
debt securities of the sovereign. These investment decisions are presumably based on a belief that industrialized countries are less likely than some of their emerging market brethren to risk eroding future investor confidence by opportunistically changing their own law in order to reduce government debt service burdens.

No country in Greece's position would lightly consider a change of local law as an easy method of dealing with a sovereign debt crisis. The following factors, among others, counsel extreme caution before embarking on such a remedy.

- If done once, future investors will fear that it could be done again. The debtor country may therefore be compelled in future borrowings (in which international investor participation is sought) to specify a foreign law as the governing law of its debt instruments.

- A dramatic change in local law by one country might allow a worm of doubt to slip into the heads of capital market investors in other similarly-situated countries, driving up borrowing costs around the board.

- The official sector supporters of the debtor country will presumably balk at any action of this kind that could unleash the forces of contagion and instability upon other countries whose debt stocks also contain predominantly local law-governed instruments.

- The more dramatic or confiscatory the effect of the change of law, the higher the likelihood that it would be subject to a successful legal challenge. More on this below.

One legislative measure that might be perceived as balanced and proportional in these circumstances, however, would be to enact what amounts to a statutory collective action clause. It could operate in this way: local law would be changed to say that if the overall exchange offer is supported by a supermajority of affected debtholders (say, $75 \%$, to use the conventional CAC threshold), then the terms of any untendered local law bonds would automatically be amended so that their payment terms (maturity profile and interest rate) match those of one of the new instruments being issued in the exchange. 
Such a law, let's call it a "Mopping-Up Law", would thus operate in the manner of a contractual collective action clause in a syndicated debt instrument. Once the supermajority of creditors is persuaded to support an amendment to the payment terms of the instrument, their decision automatically binds any dissident minority.

Viewed another way, the Mopping-Up Law would merely replicate at the level of the sovereign borrower the same protection enjoyed by corporate borrowers in many countries, including Greece. For example, we understand that in corporate reorganization proceedings under Greek bankruptcy law, if a plan of reorganization is accepted by two thirds of the affected creditors (including at least 40 percent of "privileged claims" such as secured or senior claims), it will -- with court approval -- bind all creditors. A Mopping-Up Law would achieve a similar result but at the level of a sovereign borrower in need of a debt reorganization.

Facilitating a sovereign debt restructuring through some form of Mopping-Up Law would be consistent with the fundamental principle that a sovereign debtor bears the burden of persuading its creditors that a debt restructuring is essential, that the terms of the restructuring are proportional to the debtor's needs, and that the sovereign is implementing economic policies designed to restore financial health. The only question is whether the sovereign must persuade every last debtholder of these elements, or just a specified supermajority of affected creditors. The trend in recent years, as evidenced by the rapidity with which CACs have been introduced into New York-law sovereign bonds, is in favor of the supermajority threshold.

Even the relatively mild step of facilitating a debt restructuring through the passage of a Mopping-Up Law of some kind, however, could draw a legal challenge. In the case of Greece, such a challenge could come from three possible sources. The first is Article 17 of the Greek Constitution. That Article declares that no one shall be deprived of property "except for public benefit" and conditional upon payment of full compensation corresponding to the value of the expropriated property. The question, it seems to us (non-Greek lawyers that we are), is whether a mandatory alteration of the payment terms of a local law Greek bond in the context of a generalized debt restructuring could be said to impair the value of that bond; an instrument that, in the absence of a successful restructuring, would have in any event been highly impaired in value. Also of possible relevance may be Article 106 of the Greek Constitution which gives the State broad powers to "consolidate social peace and protect the general interest." 
A second source of possible legal concern might lie in the European Convention on Human Rights and its Protocols. Article 1 of Protocol No. 1 protects the right to the "peaceful enjoyment of possessions". This right may be restricted only in the public interest and only through measures that do not impose an individual and excessive burden on the private party. That said, Article 15 of the Convention permits measures, otherwise inconsistent with the Convention, to deal with a "public emergency threatening the life of the nation".

Finally, foreign holders of local law-governed Greek bonds subject to the Mopping-Up Law might look to Greece's Bilateral Investment Treaties for redress. BITs protect against expropriation without compensation, as well as unfair and inequitable treatment. It appears that Greece has signed more than 40 BITs with bilateral partners.

Assuming some version of a Mopping-Up Law could survive any legal challenge, however, it could have significant tactical implications for a Greek debt restructuring. More than $90 \%$ of Greek bonds are governed by local law. If, to use our example, holders of $75 \%$ of all eligible bonds (local law and foreign law) were to support a restructuring, our version of a Mopping-Up Law should operate to ensure that more than $90 \%$ of the debt stock will be covered by the restructuring. The Mopping-Up Law would not affect holders of foreign law bonds. Participation by those holders would need to be encouraged by moral suasion and the use of contractual collective action clauses in the relevant bonds.

\section{How Long Would a Restructuring Take?}

necessary.

Our guess? If done efficiently, five to six months, less if

One month or so would be needed for preparation; one to two months for creditor consultations; one month during which the exchange offer would be in the market and road shows would take place; another four to six weeks to convene bondholder meetings for those bonds containing CACs, and two to four weeks to prepare for a closing.

If done efficiently. 